\title{
IMPACTS OF FUTURE FLOW REGIME ALTERATIONS ON IRON LOAD OCCURRENCE IN GIN RIVER, SRI LANKA
}

\author{
Thushara Navodani WICKRAMAARACHCHI ${ }^{1}$, Hiroshi ISHIDAIRA ${ }^{2}$, Jun MAGOME $^{3}$ and Nimal \\ WIJAYARATNA ${ }^{4}$ \\ ${ }^{1}$ Member of JSCE, M. Phil., Senior Lecturer, Dept. of Civil and Environmental Engineering, University of Ruhuna \\ (Hapugala, Galle, Sri Lanka) \\ ${ }^{2}$ Member of JSCE, Dr. of Eng., Associate Professor, Interdisciplinary Graduate School of Medicine and Engineering, University of \\ Yamanashi (Takeda 4-3-11, Kofu, Yamanashi 400-8511, Japan) \\ ${ }^{3}$ Member of JSCE, Dr. of Eng., Assistant Professor, Interdisciplinary Graduate School of Medicine and Engineering, University of \\ Yamanashi (Takeda 4-3-11, Kofu, Yamanashi 400-8511, Japan) \\ 4 Dr. of Eng., Senior Lecturer, Dept. of Civil \& Environment Engineering, University of Ruhuna \\ (Hapugala, Galle, Sri Lanka)
}

\begin{abstract}
This study assesses the future effects of land use and climate (rainfall) changes on river flow regime and subsequent impacts on the water quality in Gin river, Sri Lanka. Future land use in the Gin catchment was predicted using a GIS based statistical regression approach. HadRM3P Regional Climate Modelling system generated the future rainfall for the SRES A2 and SRES A1B emission scenarios. Yamanashi distributed hydrological model (YHyM/BTOPMC) was used to simulate the future hydrological conditions in the basin. Year 2020 total iron load was modeled using a rating curve constructed with the observed relationship between total iron concentration and stream flow. Results indicate that future total iron load would be peaked in June following more pronounced peak flows under SRES A2 scenario compared to the current peak load in October. Due to the future extreme rainfall events, peak total iron load occurrence in Gin river could be increased by about $40 \%$.
\end{abstract}

Key Words: Climate change; Distributed hydrologic modeling; Gin river; Land use; Total iron

\section{INTRODUCTION}

Land use composition and climatic pattern variations in catchments have been shown to affect the river flow regime and subsequently bring adverse impacts on the river water quality ${ }^{1}$. In the Sri Lankan context, the major intentional pressures on water resources are agriculture, urbanization and industrialisation that change land use patterns. Excessive use of agrochemicals and chemical fertilizers, release of industrial effluents, domestic waste and sewage, and dumping of solid waste into waterways cause unintentional pressures. These pressures collectively interact resulting in complex impacts on water resources ${ }^{2}$.

Gin catchment is about $932 \mathrm{~km}^{2}$ and the catchment area at Baddegama river gauging station $\left(6^{\circ} 11^{\prime} 23^{\prime \prime} \mathrm{N}, 80^{\circ} 11^{\prime} 53^{\prime \prime}\right.$ E) is $780 \mathrm{~km}^{2}$. The catchment is located approximately between longitudes $80^{\circ} 08^{\prime \prime} \mathrm{E}$ and $80^{\circ} 40^{\prime \prime} \mathrm{E}$, and latitudes $6^{\circ} 04 " \mathrm{~N}$ and $6^{\circ} 30^{\prime \prime} \mathrm{N}$ (Fig.1). Rainfall pattern in the catchment is of bi-modal, falling between May and September (Southwest monsoon, which is the major rainfall season), and again between November and February (Northeast monsoon) followed by the inter-monsoon rains during the remaining months of the year.

Gin River is the most important drinking water source to cover the water supply requirement in the Galle district and it is the primary drinking water source, from which pipe-borne water is supplied to Galle city, the capital of Southern Sri Lanka, averaging 0.7 million cubic meters per month. Moreover, people living adjacent to the Gin river use river water for their daily water consumptions. A study carried out recently by Wickramaarachchi et $\mathrm{al}^{3)}$ on the quality of water in Gin river revealed that the concentration of total iron, which ranged 


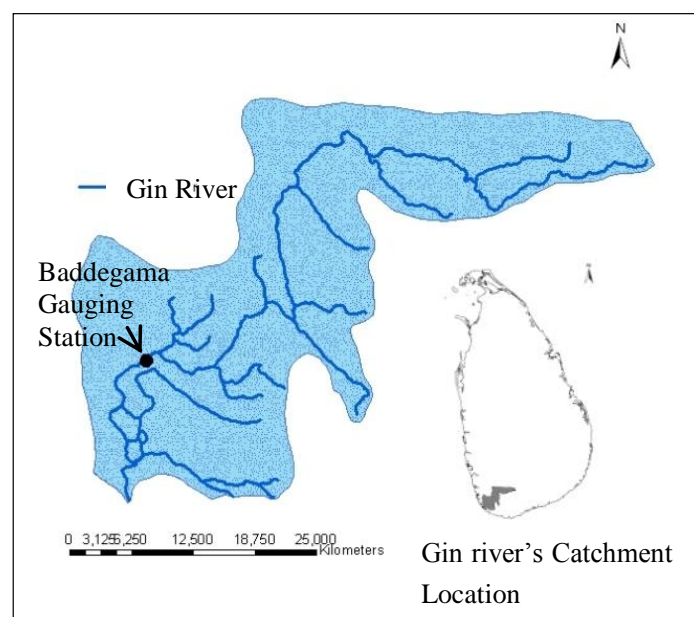

Fig.1 Gin river, its catchment location, and Baddegama river gauging station.

between $0.8 \mathrm{mg} / \mathrm{l}$ and $4.8 \mathrm{mg} / \mathrm{l}$ in Gin river water significantly exceeded the highest desirable limit for potable water ${ }^{4)}$ and the maximum permissible limit for inland waters ${ }^{5)}$ of Sri Lanka. Also due to the current development activities in the Southern region owing to substantial land use change, it is believed to be induced some impacts on the quality of water in the Gin river. According to the sustainable water supply development strategies launched by the government, it is expected to achieve $94 \%$ safe drinking water supply by 2015 and $100 \%$ by $2020^{6)}$ (in seven years time). In line with above strategies, this study aims at understanding the total iron loads in Gin river likely to occur in future (year 2020), subsequent to the flow regime alterations owing to land use and climate change.

\section{MATERIALS AND METHODS}

\section{(1) Land use change}

Available land use types in the catchment were reclassified into five classes that represent the main land use types of the area; 'forest', 'paddy cultivation', 'other cultivation', 'homestead/garden', and 'other'. 'Other cultivation' category includes export-oriented crops; tea, rubber and cinnamon. 'Other' category basically includes water bodies. Future land use in the Gin catchment was predicted using a GIS based statistical regression approach ${ }^{7,8)}$. In this study, probability of occurrence of a certain land use type was predicted by the socioeconomic, proximity and biophysical driving factors correlated with the five major classes of land use.

The function between the relative probability of finding different land use types at a particular location and the socioeconomic, proximity and biophysical driving factors was defined using the binary logistic regression which used to link the driving factors to the land use distribution. The probability of a certain grid cell to be devoted to a land use type given by;

$$
\begin{aligned}
\log \left(\frac{P_{i, u}}{1-P_{i, u}}\right)= & \beta_{0, u}+\beta_{1, u} X_{1, i}+\beta_{2, u} X_{2, i}+\cdots+ \\
& \beta_{n, u} X_{n, i}
\end{aligned}
$$

where $P_{i, u}$ is the probability of grid cell $i$ for the occurrence of the considered land use type $u, \beta$ is the regression coefficient and $X$ is the driving factor ${ }^{7}$.

Future land use demand was quantitatively determined using population forecast along with the growth ratio; the ratio of developed land growth to population growth ${ }^{9)}$.

$$
A_{2}=A_{1}\left\{1+R\left(\frac{\left(P_{2}-P_{1}\right)}{P_{1}}\right)\right\}
$$

where $A_{2}$ and $A_{1}$ are future and current area of considered land use type $\left(\mathrm{km}^{2}\right)$, respectively; $P_{2}$ and $P_{1}$ are future and current population, respectively; and $R$ is the growth ratio, the ratio between growth rate of considered land use type between 1983 and $1999(\%)$ and population growth rate (\%). Past and present population of the area and the average annual population growth rates were obtained from the census of 1981 and 2011. Future population up to year 2020 was determined according to the 'standard' rate of growth of population, Sri Lanka ${ }^{10)}$.

Allocation of land use change was made in an iterative procedure given the probability maps, the decision rules (which indicate the areas where the land use changes are restricted through policies or tenure status), and conversion elasticities (which determine the reversibility of land use change) in combination with the actual land use map in 1983, and the demand for the different land use types (Fig.2). Observed land use map in 1999 was used in validating the predictions. Validation of logistic regression analysis was tested using the Relative Operating Characteristic (ROC) analysis. ROC values ranged between 0.5 and $1 ; 0.5$ for completely random and 1 for the perfect fit, respectively. The spatial distribution of all land use types could well be explained by the selected driving factors as indicated

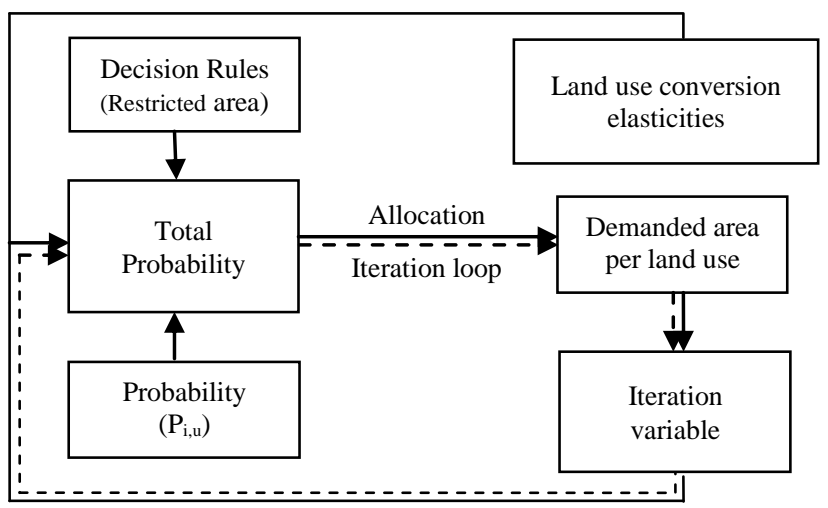

Fig.2 Representation of the iterative procedure for land use change allocation. 
by the comparatively high ROC test statistics ${ }^{8) .}$

\section{(2) Climate change impacted precipitation}

Future rainfall was estimated from the PRECIS run using HadRM3P, a high-resolution (25 x $25 \mathrm{~km}$ grid size) Regional Climate Modelling (RCM) system developed by the Met Office Hadley Centre, United Kingdom for SRES A2 and SRES A1B emission scenarios. Hadley Centre RCM has shown its capability in better capturing the influence of variations in monsoon precipitation in the Indian subcontinent ${ }^{11)}$.

SRES A2 emission scenario assumes a high population growth, and less concern for rapid economic development, whereas in the SRES A1B scenario assumes rapid economic and population growth that peaks in mid century and declines thereafter.

\section{(a) Daily scaling method}

This study utilizes the 'daily scaling' method ${ }^{12)}$, ${ }^{13)}$ that considers daily patterns of rainfall change simulated by the RCM. Daily scaling method considers changes in extreme daily rainfall and changes in the frequency of wet days. As explained by Kiem et $\mathrm{al}^{12)}$, and Harrold et $\mathrm{al}^{13)}$, the principle of daily scaling, applies relative changes in the distribution of daily rainfall at the RCM scale to rainfall at the catchment scale, in order to produce a scenario of climate change impacted catchment rainfall at a particular station. Ranked daily HadRM3P RCM precipitation at the grid containing the particular station during 2001-2004 and 2020 is compared. The ranked daily precipitation differences were expressed as ratios relative to the 2001-2004 precipitation. These ratios were then used to scale the 30 years (1980-2009) of ranked historical daily precipitation to provide year 2020 daily precipitation at the particular station.

\section{(3) Hydrologic simulation}

The University of Yamanashi Distributed Hydrological Model (YHyM) with block wise use of TOPMODEL and Muskingum-Cunge method (BTOPMC) is a grid based distributed hydrological model. In the YHyM, runoff is generated based on the TOPMODEL concept and flow routing is carried out using the Muskingum Cunge method. YHyM/BTOPMC was chosen based on its proven applications in many basins around the world. An extensive description of the YHyM/BTOPMC can be found in Takeuchi et $\mathrm{al}^{14)}$.

Hydrologic model calibration (1997-2001) and validation (2002-2006) were performed by comparing modeled hydrographs with monitored stream flow data from the Baddegama and Tawalama river gauging stations. Model performance was evaluated by the Nash-Sutcliffe Efficiency (E) and the volume ratio of total simulated discharge to total observed discharge $\left(\mathrm{V}_{\mathrm{r}}\right)$ (Table 1). The calibrated and validated YHyM/BTOPMC performed well at simulating the major hydrological characteristics in Gin river basin ${ }^{15), 16)}$. Year 2020 daily discharge was predicted using year 2020 land use projections and SRES A2 and SRES A1B precipitation data.

Table 1 YHyM/BTOPMC model performance.

\begin{tabular}{|l|c|c|c|c|}
\cline { 2 - 5 } \multicolumn{1}{c|}{} & \multicolumn{2}{c|}{ Calibration } & \multicolumn{2}{c|}{ Validation } \\
\cline { 2 - 5 } \multicolumn{1}{c|}{} & Agaliya & Tawalama & Agaliya & Tawalama \\
\hline$V r \%$ & 67.63 & 53.75 & 62.73 & 48.31 \\
\hline
\end{tabular}

\section{(4) Water quality constituent estimation}

LOADEST, a load-discharge rating curve for estimating constituent loads in rivers is used in this study to develop regression model and estimate loads of total iron ${ }^{17}$. LOADEST uses time series stream flow data and constituent concentrations to develop and calibrate a regression model that describes constituent loads in terms of various functions of stream flow and time. For total iron, data of 106 water quality samples tested daily at monthly frequency between January 2001 and November 2009 were collected from the National Water Supply and Drainage Board (Southern), Sri Lanka. Daily stream flow data at the Baddegama gauging station for the same period were collected from the Department of Irrigation, Sri Lanka. Total iron concentration observations were used in conjunction with corresponding observed stream flow data to develop and calibrate the regression model using adjusted maximum likelihood estimation (AMLE) method. The AMLE was used after checking that regression residuals were normally distributed. The regression model developed for total iron (Table 2) showed higher coefficient of determination $\left(\mathrm{R}^{2}=85.72 \%\right)$ reflecting a strong relationship between the estimated rating curve and measured total iron loads. Total iron load estimates for year 2020 were calculated using daily discharge output by the YHyM/BTOPMC.

\section{RESULTS AND DISCUSSION}

\section{(1) Future land use and rainfall}

\section{(a) Future Land use}

Year 2020 land use envisaged a predominant replacement of cultivations by forest and homestead/garden (Fig.3) which seems to have driven jointly by the change in agricultural practices and increase in population. About 29\% forest cover in the early $80 \mathrm{~s}$, has been increased closer to $30 \%$ 
Table 2 Regression model developed for total iron using LOADEST.

\begin{tabular}{|c|c|c|c|c|c|c|c|c|}
\hline \multirow[t]{2}{*}{ Regression model } & \multicolumn{7}{|c|}{ Model Coefficients ${ }^{(a)}$} & \multirow[t]{2}{*}{$\mathrm{R}^{2}(\%)$} \\
\hline & $\mathrm{a} 0$ & a1 & $\mathrm{a} 2$ & a3 & $\mathrm{a} 4$ & a5 & a6 & \\
\hline $\begin{array}{l}\operatorname{Ln}(\mathrm{L})=\mathrm{a} 0+\mathrm{a} 1 \mathrm{LnQ}+\mathrm{a} 2 \mathrm{LnQ}^{2}+\mathrm{a} 3 \operatorname{Sin}(2 \pi \\
\mathrm{T})+\mathrm{a} 4 \operatorname{Cos}(2 \pi \mathrm{T})+\mathrm{a} 5 \mathrm{~T}+\mathrm{a} 6 \mathrm{~T}^{2}\end{array}$ & $\begin{array}{l}8.69 \\
(0.08)\end{array}$ & $\begin{array}{l}1.37 \\
(0.06)\end{array}$ & $\begin{array}{l}0.02 \\
(0.06)\end{array}$ & $\begin{array}{l}0.01 \\
(0.07)\end{array}$ & $\begin{array}{l}-0.14 \\
(0.07)\end{array}$ & $\begin{array}{l}-0.03 \\
(0.02)\end{array}$ & $\begin{array}{l}0.02 \\
(0.01)\end{array}$ & 85.72 \\
\hline
\end{tabular}

(a) Standard deviation of the model coefficients are shown in parentheses.

$\mathrm{L}$ is the constituent load; $\mathrm{Q}$ is the stream flow; $\mathrm{R}^{2}$ is the coefficient of determination for the regression model.

$\mathrm{LnQ}=\mathrm{Ln}$ (stream flow) - center of $\mathrm{Ln}$ (stream flow); $T=$ decimal time - center of decimal time.

Relationships are considered to be significant at $p<0.05$. Explanatory variables were centered to eliminate the collinearity ${ }^{17)}$.
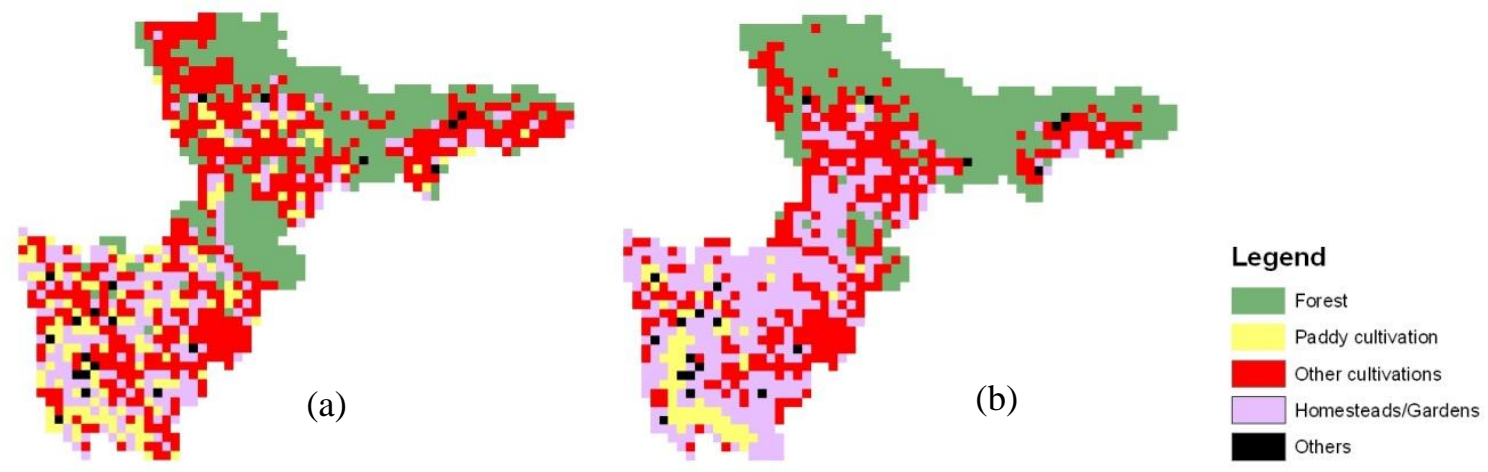

Fig.3 Observed and predicted land use.

(a) 1983 observed Land use (b) Year 2020 predicted Land use

and $32 \%$ in the late 90 s and in 2020 , respectively. Expansion of forest area occurred basically at the forest frontiers. About $7 \%$ of the paddy cultivated areas that existed in 1983 had been converted to other land uses by 2020 . About $40 \%$ of land devoted to the other cultivation decreased to $30 \%$ between 1983 and 2020. This enormous reduction in agricultural areas is supported by the country's economic policies which changed in late 70s. The government policy has been of support for market oriented open economy encouraging private enterprise, changing peoples' preferences from farming to other employments. Homestead/garden area expanded by $14 \%$ between 1983 and 2020 as a consequence of the growing population. These expansions of dwelling zones were taking place in small and isolated cultivated lands in close proximity to existing homestead/garden.

\section{(b) Future rainfall}

All grid squares covering the Gin river basin will experience a decrease in the number of wet days [having rainfall $>0.5 \mathrm{~mm}^{12)}$ ] in year 2020 . Magnitude of total annual precipitation in year 2020 is expected to decrease by about $10 \%$ and $40 \%$ under the SRES A2 and SRES A1B scenarios, respectively. But an increase of extreme events is noted under SRES A2.

Despite the fact that this study considered a single RCM and two SRES emissions scenarios, future change in hydroclimatological variables needs to be projected based on output from several different climate models operating under a variety of scenarios.

\section{(2) Future hydrological conditions in the Gin river basin at Baddegama}

The hydrological response to the two forcing SRES scenarios as simulated by the YHyM/BTOPMC is depicted using the flow duration curves (Fig.4).

Increased peak flow (largely due to rainfall generated runoff) is more pronounced, for the SRES A2 scenario, as a result of the increased extreme events. According to the simulated annual water balance, evapotranspiration, ground water recharge and base flow are expected to slightly decrease under both scenarios owing to decreased future rainfall and substantial replacement of catchment's pervious areas in future. Year 2020 total annual runoff is predicted to decline for the SRES A2 and

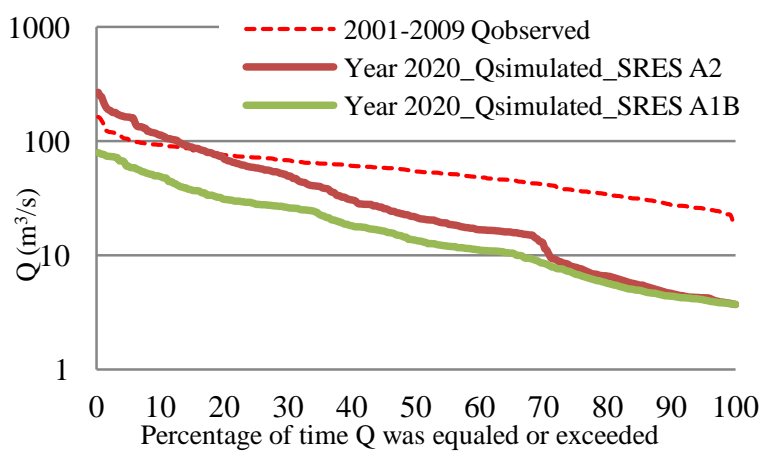

Fig.4 Flow duration Curves: year 2020 and current (2001-2009) 


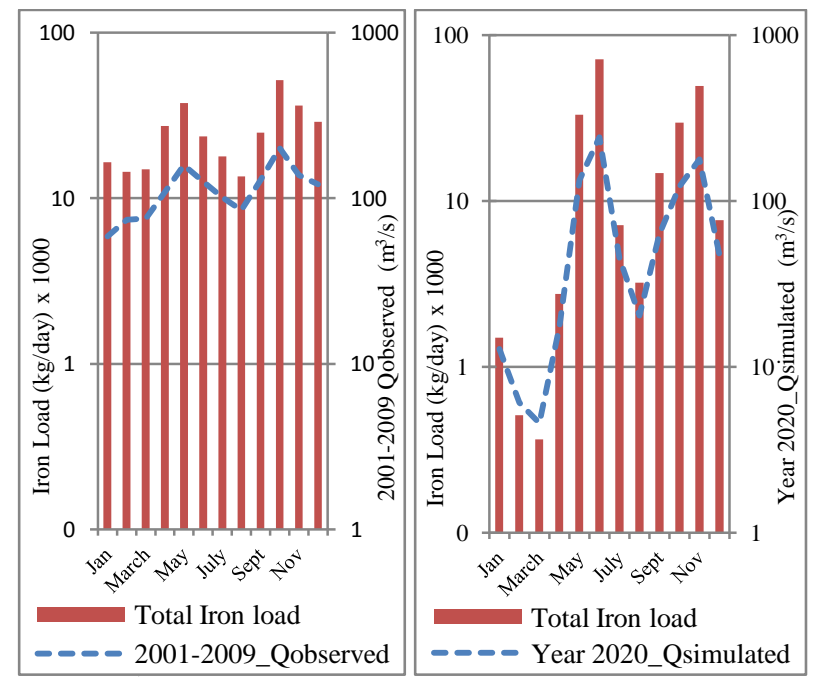

Fig.5 $90^{\text {th }}$ percentile of the total iron load (bar chart) and monthly discharge (blue broken line)

Left: Current (average of 2001-2009), Right: Year 2020.

SRES A1B scenarios by $15 \%$ and $60 \%$, respectively.

Though this study included future projections for both SRES A2 and SRES A1B scenarios, in most of the climate adaptation studies carried out, it has been identified that the most matching scenario for Sri Lankan conditions is SRES A2. This is further explained by De Silva et $\mathrm{al}^{18)}$. Despite the fact that SRES A1B runoff decreases by four fold of SRES A2, flows with high magnitudes are expected to occur under SRES A2 scenario (Fig.4). In addition, according to Wickramaarachchi et $\mathrm{al}^{3)}$, higher concentrations of total iron were in the range of higher flows. Thus the present study opted to consider total iron load variation in the future flow regime for only SRES A2 scenario at Baddegama river gauging station .

\section{(3) Flow regime induced changes in water quality}

(a) Total iron loads in future river flow

Current and future total iron loads were estimated based on $90^{\text {th }}$ percentile of the monthly load (Fig.5). This was done because the $90^{\text {th }}$ percentile of constituent load in a particular month provides more conservative estimate than the median load, giving an appropriate margin of safety to protect against any underestimation of the median. Peak total iron load occurrences in future showed remarkable temporal difference from the current and indicated significant fluctuation in wide range (71 tons/day to 0.4 tons/day) compared to the current (51 tons/day to 14 tons/day). Generally at the catchment level, future total iron load peaked during June, while October displayed the peak value during 2001-2009. Analysis revealed that due to the future extreme rainfall events, peak total iron load occurrence in Gin river could be increased by about $40 \%$. In line with the significant decrease of future discharge in year 2020-March, the total iron load was slated to the lowest while August was having the lowest total iron load, during 2001-2009.

Generally flow weighed concentration assessments highlight the interaction between flow and particle associated constituents, and enable concentrations to be assessed despite the variations in flow. In the case of total iron, large estimated loads would be expected in high flows, because iron particulate matter was increased during high flows, not diluted.

\section{(4) Total iron comparison with the water quality standards}

Percentage reductions necessary to bring the $90^{\text {th }}$ percentile of year 2020 total iron load estimates down to the water quality criterion $(0.3 \mathrm{mg} / \mathrm{l})^{4)}$ were calculated (Fig.6). Similar to the situation during 2001-2009, percentage reductions of year 2020 total iron load necessary to meet the highest desirable level for potable water remain significant under all the flow regimes. Intensified draining of exposed laterite soils enriched with iron, which are commonly present in the area ${ }^{19)}$ may be contributing to the higher concentrations of total iron. During $2001-2009,91 \%$ and $88 \%$ reductions of total iron load were required to meet the water quality criterion during the highest and high flows, respectively. Comparable reductions required in year 2020 have shown slight increase, i.e. $92 \%$ and $90 \%$ during the highest and high flows, respectively (Fig.6).

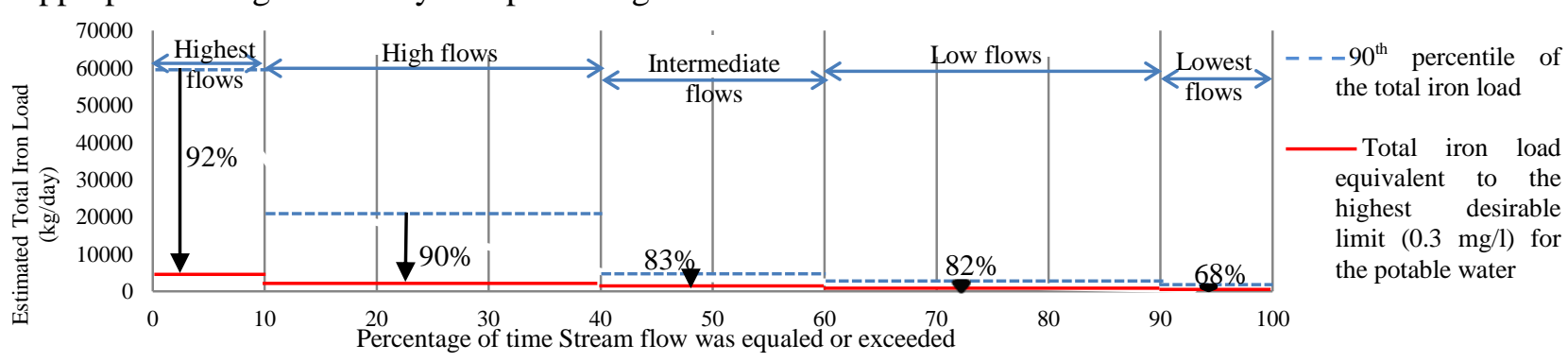

Fig.6 $90^{\text {th }}$ percentile of the year 2020 total iron load and the percentage reductions of the total iron load necessary to meet the water quality standards. 


\section{CONCLUSIONS}

This study revealed that future land use and climate (rainfall) changes have the potential of changing the total iron loads in Gin river flow subsequent to the increased extreme rainfall events particularly for SRES A2 scenario. Future peak total iron load occurrences (monthly basis) showed significant temporal deviation from the current.

Direct impact of land use change on river water quality is not assessed in the present study. Therefore more rigorous qualitative methodology will be undertaken in future to assess the above, in providing wider perspective to the present study.

Findings in this research might be useful in launching preparatory actions to minimize the plausible impacts on river water quality due to the changes in flow regime. It would be interesting to assess total iron loads in response to other climate emission scenarios to see what difference could be obtained.

ACKNOWLEDGMENT: Authors gratefully acknowledge National Water Supply and Drainage Board (Southern), Sri Lanka for providing the water quality data of Gin river. Authors are grateful to Ms Grace Redmond, UK Met Office Hadley Centre for providing climate projections. Sincere appreciation is extended to University of Yamanashi, Japan and Japan Society for Promotion of Science (JSPS) for the technical and financial support for the study.

\section{REFERENCES}

1) Mander, U., Kull, A., Tamm, V., Kuusemets, V. and Karjus, R.: Impact of climatic Fluctuations and land use change on runoff and nutrient losses in rural landscape. Landscape Urban Plan, Vol.41, pp.229-238, 1988.

2) U.N. Environment Programme (UNEP): State of the Environment Sri Lanka. United Nations Environment Programme, Regional Resource Centre for Asia and the Pacific (UNEP-RRC.AP), 2001.

3) Wickramarachchi, T.N., Ishidaira, H. and Wijyaratna,T.M.N.: Variation of constituent loads and concentrations with the flow in Gin river, Sri Lanka. $J$ Natn Sci Foundation Sri Lanka, Vol.41(3), pp.237-247, 2013.

4) Sri Lanka Standards Institute (SLS): Sri Lanka Standards for Potable Water - SLS 614. Sri Lanka Standards Institute, Colombo 08, 1983.

5) Central Environmental Authority (CEA): Proposed Ambient Water Quality Standards for Inland Waters of Sri Lanka. Central Environmental Authority, Battaramula, 2001.

6) Policy and Planning Division-National Water Supply and Drainage Board: Strategies for sustainable water supply development in line with Mahinda Chintana, The emerging wonder of Asia, 2011.
7) Verburg, P.H., Soepboer, W., Veldkamp, A., Limpiada, R., Espaldon, V. and Mastura, S.S.A.: Modeling the spatial dynamics of regional land use: the CLUE-S model. Environ Manage, Vol.30 (3), pp.391-405, 2002.

8) Wickramaarachchi, T.N., Ishidaira, H., and Wijayaratna, T.M.N.: Projecting land use transitions in the Gin Catchment, Sri Lanka. Res J Environ Earth Sci, Vol.5(8), pp. 473-480, 2013.

9) Craig, E. C., Jeffery, A., and Kang, S.L.: Modeling growth and predicting future developed land in the Upstate of South Carolia. Strom Thurmond Institute, Clemson University, 2007.

10) De Silva, W.I.: A population projection of Sri Lanka for the millennium, 2001-2101: trends and implications. Institute for Health Policy, Colombo, Sri Lanka, 2007.

11) Jones, R.G., Noguer, M., Hassell, D.C., Hudson, D., Wilson, S.S., Jenkins, G.J. and Mitchell, J.F.B.: Generating high resolution climate change scenarios using PRECIS, Met Office Hadley Centre, Exeter, UK, 40pp, 2004.

12) Kiem A.S., Ishidaira H., Hapuarachchi H.P., Zhou M.C., Hirabayashi Y. and Takeuchi K.: Future hydroclimatology of the Mekong River basin simulated using the high-resolution Japan Meteorological Agency (JMA) AGCM. Hydrol Process, Vol.22, pp.1382-1394, 2008.

13) Harrold, T.I., Chiew, F.H.S., Siriwardena, L.: A method for estimating climate change impacts on mean and extreme rainfall and runoff. In MODSIM 2005 International Congress on Modelling and Simulation, Zerger A, Argent RM (eds). Modelling and Simulation Society of Australia and New Zealand: Melbourne, pp.497-504, 2005.

14) Takeuchi, K., Hapuarachchi, P., Zhou, M., Ishidaira, H., and Magome, J.: A BTOP model to extend TOPMODEL for distributed hydrological simulation of large basins. Hydrol Processes, Vol.22, pp.3236-3251, 2008.

15) Wickramaarachchi, T.N., Ishidaira, H. and Wijayaratna, T.M.N.: An Application of Distributed Hydrological Model, YHyM/BTOPMC to Gin Ganga Watershed, Sri Lanka, Engineer, Journal of the Institution of Engineers Sri Lanka, Vol.45(2), 2012.

16) Wickramaarachchi, T.N., Ishidaira, H. and Wijayaratna, T.M.N.: Applicability of global public domain data versus local detailed data for distributed hydrologic modelling: A study form Gin river basin Sri Lanka. Applied Water Science, Vol.3(2), pp.545-557, 2013.

17) Runkel, R.L., Crawford, C.G. and Cohn, T.A.: Load Estimator (LOADEST): A FORTRAN program for estimating constituent loads in streams and rivers. U.S.Geological Survey Techniques and Methods, Book 4, chapter A5, pp. 69. US Geological Survey, USA, 2004.

18) De Silva, C. S., Weatherhead, E. K., Knox, J. W., and Rodriguez, D. J. A.: Predicting the impacts of climate change-A case study of paddy irrigation requirements in Sri Lanka, Agr water manage, Vol.93, pp.19-29, 2007.

19) Herath, J.W.: Genesis and constitution of Sri Lanka laterites. J Natn Sci Council Sri Lanka, Vol.11(2), pp.277 292, 1983.

(Received September 30, 2013) 